\title{
The Technical Quality of the Wood of Scots Pine (Pinus sylvestris L.) of Diverse Genetic Origin
}

\author{
Eliza Konofalska ${ }^{1, *}$, Paweł Kozakiewicz ${ }^{2} \mathbb{D}$, Włodzimierz Buraczyk ${ }^{3}$, Henryk Szeligowski ${ }^{3}$ \\ and Hubert Lachowicz ${ }^{4}$
}

Citation: Konofalska, E.;

Kozakiewicz, P.; Buraczyk, W.; Szeligowski, H.; Lachowicz, H. The Technical Quality of the Wood of Scots Pine (Pinus sylvestris L.) of Diverse Genetic Origin. Forests 2021, 12, 619. https://doi.org/10.3390/ f12050619

Academic Editor: Angela Lo Monaco

Received: 7 April 2021

Accepted: 11 May 2021

Published: 14 May 2021

Publisher's Note: MDPI stays neutral with regard to jurisdictional claims in published maps and institutional affiliations.

Copyright: (c) 2021 by the authors. Licensee MDPI, Basel, Switzerland. This article is an open access article distributed under the terms and conditions of the Creative Commons Attribution (CC BY) license (https:// creativecommons.org/licenses/by/ $4.0 /)$.
1 Kielce Forest District, Hubalczyków 15, 25-668 Kielce, Poland

2 Department of Wood Science and Wood Preservation, Institute of Wood Sciences and Furniture, Warsaw University of Life Sciences-SGGW, Nowoursynowska 159 St., 02-776 Warsaw, Poland; pawel_kozakiewicz@sggw.edu.pl

3 Department of Forest Silviculture, Institute of Forest Sciences, Warsaw University of Life Sciences-SGGW, Nowoursynowska 159 St., 02-776 Warsaw, Poland; wburaczyk@wp.pl (W.B.); henryk_szeligowski@sggw.edu.pl (H.S.)

4 Department of Forest Utilization, Institute of Forest Sciences, Warsaw University of Life Sciences-SGGW, Nowoursynowska 159 St., 02-776 Warszawa, Poland; hubert_lachowicz@sggw.edu.pl

* Correspondence: konofalskaeliza@gmail.com

Abstract: This work contains the preliminary results of research into the technical quality of the wood from Scots pine trees of diverse genetic origin, grown on an experimental plot at the Forest Experimental Station in Rogów. The following are the parent stands, numbered: 5 (the Tucholskie Forest $130 \mathrm{~m}$ a.s.l.), 7 (the Napiwodzko-Ramuckie Forest $145 \mathrm{~m}$ a.s.l.), 10 (the Piska Forest $145 \mathrm{~m}$ a.s.l.), 12 (the Biała Forest $95 \mathrm{~m}$ a.s.l.), 13 (the Namysłowsko-Ostrzeszowskie Forest $190 \mathrm{~m}$ a.s.l.), 15 (the Knyszyńska Forest $165 \mathrm{~m}$ a.s.l.), and 16 (the Nowotarskie Forest $590 \mathrm{~m}$ a.s.1.). The tested wood was obtained in 2018 from trees aged 52 years. The research material came from 100 trees in total. After felling, two logs approximately $0.5 \mathrm{~m}$ in length were cut from each tree. The height on the tree from which the material was taken ranged from breast height $(1.3 \mathrm{~m})$ to approximately $2.5 \mathrm{~m}$. Next, planks were cut from the logs in a north-south direction; these were precisely described and then left to season. The work included the measurement and statistical analysis of one physical property, wood density $\left(\mathrm{kg} / \mathrm{m}^{3}\right)$, and of the following mechanical properties: compressive strength along the fibres, $\mathrm{Rc}_{12}(\mathrm{MPa})$; static bending strength, $\operatorname{Rg}_{12}(\mathrm{MPa})$; modulus of elasticity under static bending, $\mathrm{Eg}_{12}(\mathrm{MPa})$; and indices of strength quality of the tested mechanical properties, $\mathrm{JRc}_{12}$, $\mathrm{JRg}_{12}$, and $\mathrm{JEg}_{12}(\mathrm{~km})$. The origin of the logs was shown to have a significant influence on wood density, compressive strength, static bending strength, and modulus of elasticity under static bending. The highest mean density was found for trees originating from stand $10\left(537 \mathrm{~kg} / \mathrm{m}^{3}\right)$. The highest values of compressive strength were obtained for trees originating from stands 5 (45 MPa), and the highest static bending strength and modulus of elasticity under static bending were obtained for trees originating from stand 12 (102 and $9825 \mathrm{MPa}$, respectively).

Keywords: Pinus sylvestris L.; wood density; mechanical properties; technical quality of wood

\section{Introduction}

Scots pine (Pinus sylvestris L.) has a range that covers the whole of Scandinavia, northeastern areas of European Russia, and Siberia, extending eastward as far as the Sea of Okhotsk and the Sea of Japan. In Poland, it is a dominant forest species, covering 66.5\% of the total forest area, according to figures for 1 January 2017 [1]. It is found from sea level to mountain peaks up to around $2700 \mathrm{~m}$ above sea level in the Caucasus [2]. In Poland, it occurs mainly in lowland areas, reaching elevations of $700 \mathrm{~m}$ in the Carpathians, although individual trees are found up to $1100 \mathrm{~m}$ above sea level [3]. It is also the most important forest-forming species in Poland with great real and potential for use in the wood industry [4]. 
Pine wood is valued and widely used not only due to its availability but also because of its physical and mechanical properties. Its technical properties depend, among other things, on its geographical origin. Paschalis [5] showed that the properties of pine wood deteriorate in a direction from north to south while on the east-west axis, there is no definite tendency. It is thus generally believed that pine wood from northern parts of Poland is superior, offering greater density and strength [6,7].

The technical quality of wood is affected by a number of factors. It depends mainly on geographical location, habitat type, and the quality of planting material [4,8-11]. The effects of habitat type were studied by Józefaciuk and Laurow [12] and, later, also by Krzysik [13]. Genetics, environment, and human factors can determine the dendrometric features of trees [14], and the properties and structure of the wood [15]. Wood quality may be influenced by genotype. The genome may exhibit phenotypic features and helps determine resistance to internal and external factors. It has been demonstrated, for example, that branch thickness is genetically conditioned [16,17].

Scots pine (Pinus sylvestris L.) is a species with a very wide natural range. Because it grows in different climatic and soil conditions, it exhibits great variation with regard to the morphology, yield, and quality of its timber. The most important method enabling the evaluation of variability between and within populations of forest trees is comparative provenance experiments.

The goal of this work was to investigate selected physical and mechanical properties of the wood of Scots pine (Pinus sylvestris L.) with seven different genetic origins, grown on an experimental plot at the Forest Experimental Station in Rogów.

\section{Materials and Methods}

\subsection{Study Site}

This work contains the preliminary results of research into the technical quality of the wood from Scots pine trees of diverse genetic origin, grown on an experimental plot at the Forest Experimental Station in Rogów. The studied trees are the offspring of seven parent populations of Scots pine growing in areas of mixed broadleaved forest habitat (FMBF). The following are the parent stands, numbered: 5 (Lipowa, he Tucholskie Forest $130 \mathrm{~m}$ a.s.1.), 7 (Dłużek, the Napiwodzko-Ramuckie Forest $145 \mathrm{~m}$ a.s.1.), 10 (Ruciane, the Piska Forest $145 \mathrm{~m}$ a.s.l.), 12 (Jegiel, the Biała Forest $\mathrm{m} 95$ a.s.l.), 13 (Rychtal, the NamysłowskoOstrzeszowskie Forest 190 m a.s.l.), 15 (Supraśl, the Knyszyńska Forest 165 m a.s.l.), and 16 (Nowy Targ, the Nowotarskie Forest $590 \mathrm{~m}$ a.s.1.) -Figure 1.

The experimental site is located in central Poland at an elevation of $160 \mathrm{~m}$ above sea level. The average annual precipitation is $595 \mathrm{~mm}$, and the average annual air temperature is $7.2^{\circ} \mathrm{C}$. All trees from the seven parent populations grow in a fresh mixed forest habitat under identical growing conditions. The planting material was consisted of one-year seedlings. Scots pine seedlings were planting in a $1 \mathrm{~m} \times 1 \mathrm{~m}$ spacing cultivation. The area of a single plot was $255 \mathrm{~m}^{2}$. Each origin was repeated five times (in total: 35 plots), so individual origin was $1275 \mathrm{~m}^{2}$.

\subsection{Obtaining and Preparing Samples for Analysis}

The tested wood was obtained in 2018 from trees aged 52 years. The research material came from 100 trees in total. After felling, two logs approximately $0.5 \mathrm{~m}$ in length were cut from each tree. The height on the tree from which the material was taken ranged from breast height $(1.3 \mathrm{~m})$ to approximately $2.5 \mathrm{~m}$. Next, planks were cut from the logs in a north-south direction; these were precisely described and then left to season. Samples were then produced for particular types of tests in accordance with the relevant provisions of the Polish Standard PN-77/D-04227 [18] and International Standard ISO 4471:1982 [19]. 


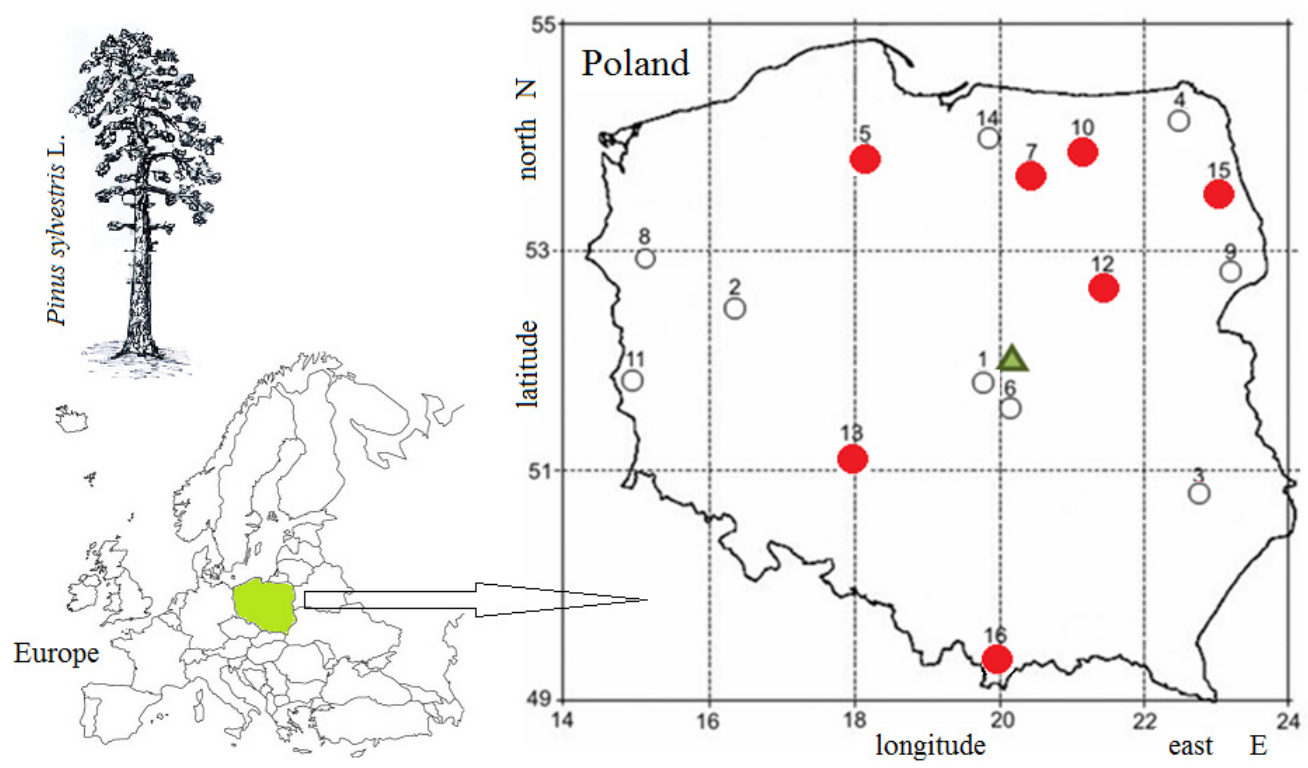

Figure 1. Genetic origin of Scots pine trees (red dots on the map), grown on an experimental plot at the Forest Experimental Station in Rogów (green triangle on the map): 5-Lipowa, in the Tucholskie Forest 130 m a.s.l.; 7-Dłużek, the Napiwodzko-Ramuckie Forest $145 \mathrm{~m}$ a.s.l.; 10—Ruciane, the Piska Forest 145 m a.s.l.; 12-Jegiel, the Biała Forest m 95 a.s.l.); 13-Rychtal, the NamysłowskoOstrzeszowskie Forest 190 m a.s.l.; 15—Supraśl, the Knyszyńska Forest 165 m a.s.l.; 16-Nowy Targ, the Nowotarskie Forest 590 m a.s.l.

\subsection{Determination of Selected Properties}

The work included the measurement and statistical analysis of one physical property, wood absolute moisture content (MC) (\%), according to standards PN-77/D-04100 [20] and ISO 13061-1:2014 [21]; density $(\rho)\left(\mathrm{kg} / \mathrm{m}^{3}\right)$ according to standards PN-77/D-04101 [22] and ISO 13061-2:2014 [23]; and the following mechanical properties: compressive strength along the fibres, $\mathrm{Rc}_{12}$ (MPa) according to standards PN-78/D-04102 [24] and ISO/DIS 13061-17:2014 [25]; static bending strength, $\mathrm{Rg}_{12}$ (MOR) (MPa) according to standards PN77/D-04103 [26] and ISO 13061-3:2014 [27]; modulus of elasticity under static bending, Eg 12 (MOE) (MPa) according to standards PN-63/D-04117 [28] and ISO 13061-4:2014 [29]; and indices of strength quality of the tested mechanical properties, $\mathrm{JRc}_{12}, \mathrm{JRg}_{12}$, and $\mathrm{JEg}_{12}(\mathrm{~km})$, calculated according to the following formula:

$$
\mathrm{J}=\frac{R(E)}{\rho} \times 100[\mathrm{~km}]
$$

The selected properties were measured at a moisture content of $12 \%$. The compressive strength along the fibres $\left(\mathrm{Rc}_{12}\right)$ was determined using an Instron 3382 machine. The modulus of elasticity under static bending $\left(\mathrm{Eg}_{12}\right)$ and the static bending strength $\left(\mathrm{Rg}_{12}\right)$ were measured using an Instron 3369 instrument.

\subsection{Statistical Analyses}

The statistical software PAST3.17 was used to analyse gathered data and a significance level of 0.05 was assumed. The statistics deal with the basic statistical characteristics of the studied origin: wood density, compressive strength along the fibres, static bending strength, modulus of elasticity under static bending, and indices of strength quality of the tested mechanical properties. All analysed wood properties significantly differed from normal distribution. We used Kruskal-Wallis and post hoc Mann-Whitney tests. 


\section{Results}

The highest mean density of wood (with an absolute moisture content of $12 \%$ ) was obtained from trees from stand $10\left(537 \mathrm{~kg} / \mathrm{m}^{3}\right)$, and the lowest was from stand $16\left(480 \mathrm{~kg} / \mathrm{m}^{3}\right)$ (Table 1). The average density of Scots pine wood for all of the studied material at Rogów Forest Experimental Station was $514 \mathrm{~kg} / \mathrm{m}^{3}$. The smallest density calculated for a single sample was $340 \mathrm{~kg} / \mathrm{m}^{3}$ (stand 16), and the largest was $783 \mathrm{~kg} / \mathrm{m}^{3}$ (stand 10).

Table 1. Characteristics of wood density $(\rho)\left(\mathrm{kg} / \mathrm{m}^{3}\right)$ of diverse genetic origins $(\mathrm{N}-$ Number of groups; M-Average; Me-Median; Min-Minimum; Max-Maximum; SD—Standard deviation; $\mathrm{V}-$ Coefficient of variation).

\begin{tabular}{cccccccc}
\hline Origin & N & M & Me & Min & Max & SD & V \\
\hline 5 & 101 & 531 & 537 & 391 & 722 & 70.4 & 13.25 \\
7 & 102 & 502 & 503 & 342 & 711 & 77.5 & 15.42 \\
10 & 92 & 537 & 541 & 362 & 783 & 84.4 & 15.70 \\
12 & 89 & 525 & 534 & 383 & 703 & 82.7 & 15.75 \\
13 & 118 & 508 & 521 & 364 & 652 & 69.4 & 13.66 \\
15 & 85 & 507 & 504 & 368 & 757 & 77.6 & 15.31 \\
16 & 72 & 480 & 480 & 340 & 609 & 67.6 & 14.09 \\
$\Sigma / M$ & 659 & 514 & 514 & 340 & 783 & 77.4 & 15.07 \\
\hline
\end{tabular}

There were statistically significant differences in the characteristics of wood density between seven genetic origins at $p<0.05$. Parent stand 16 is statistically different from the others.

The highest mean compressive strength $(\mathrm{Rc})$ was obtained from stand $5(45.45 \mathrm{MPa})$, and the lowest was from stand $16(40.14 \mathrm{MPa})$ (Table 2). For the whole of the studied material, the mean compressive strength along the fibres was $43.72 \mathrm{MPa}$, with values for individual samples ranging from a minimum of $20.33 \mathrm{MPa}$ (stand 12) to a maximum of 70.21 MPa (stand 15).

Table 2. Characteristics of compressive strength Rc (MPa) of diverse genetic origins (N-Number of groups; M-Average; Me-Median; Min-Minimum; Max-Maximum; SD—Standard deviation; $\mathrm{V}-$ Coefficient of variation).

\begin{tabular}{cccccccc}
\hline Origin & $\mathbf{N}$ & $\mathbf{M}$ & Me & Min & Max & SD & V \\
\hline 5 & 101 & 45.45 & 47.02 & 25.35 & 65.51 & 10.71 & 23.56 \\
7 & 102 & 42.59 & 43.99 & 23.30 & 67.26 & 10.61 & 24.91 \\
10 & 92 & 44.47 & 45.52 & 23.94 & 62.59 & 10.57 & 23.76 \\
12 & 89 & 44.94 & 45.85 & 20.33 & 68.66 & 12.61 & 28.05 \\
13 & 118 & 43.24 & 45.90 & 22.07 & 61.68 & 10.68 & 24.69 \\
15 & 85 & 44.64 & 44.89 & 25.03 & 70.21 & 10.78 & 24.16 \\
16 & 72 & 40.14 & 40.17 & 22.38 & 59.33 & 9.44 & 23.53 \\
$\sum / M$ & 659 & 43.72 & 44.73 & 20.33 & 70.21 & 10.89 & 24.91 \\
\hline
\end{tabular}

It was found that the analysed populations differ statistically in mean values of compressive strength at $p<0.05$. For example, stand 16 is statistically different from the others, apart from stand 7.

The highest mean static bending strength $(\mathrm{Rg})$ was found in the wood from stand 12 (102.13 MPa), and the lowest was found in stand 16 (83.53 MPa) (Table 3). The mean for the whole of the studied material was $94.45 \mathrm{MPa}$. The lowest value for an individual sample was 23.94 $\mathrm{MPa}$ (stand 5), and the highest was $169.80 \mathrm{MPa}$ (stand 12). 
Table 3. Characteristics of static bending strength $\operatorname{Rg}_{12}$ (MOR) (MPa) of diverse genetic origins (NNumber of groups; M-Average; Me-Median; Min-Minimum; Max-Maximum; SD—Standard deviation; $\mathrm{V}-$ Coefficient of variation).

\begin{tabular}{cccccccc}
\hline Origin & $\mathbf{N}$ & $\mathbf{M}$ & $\mathbf{M e}$ & $\mathbf{M i n}$ & $\mathbf{M a x}$ & $\mathbf{S D}$ & $\mathbf{V}$ \\
\hline 5 & 101 & 95.50 & 102.00 & 23.94 & 158.60 & 30.95 & 32.41 \\
7 & 102 & 93.33 & 93.06 & 32.48 & 150.30 & 29.03 & 31.11 \\
10 & 92 & 94.32 & 96.86 & 25.02 & 151.60 & 28.76 & 30.49 \\
12 & 89 & 102.13 & 109.00 & 39.21 & 169.80 & 33.17 & 32.48 \\
13 & 118 & 95.73 & 102.00 & 34.89 & 151.80 & 28.82 & 30.10 \\
15 & 85 & 94.11 & 96.77 & 39.21 & 150.00 & 28.08 & 29.83 \\
16 & 72 & 83.53 & 86.30 & 23.95 & 135.30 & 24.60 & 29.45 \\
$\sum / \mathrm{M}$ & 659 & 94.45 & 96.93 & 23.94 & 169.80 & 29.53 & 31.26 \\
\hline
\end{tabular}

There were statistically significant differences in the characteristics of static bending strength between diverse genetic origins at $p<0.05$. Parent stand 16 is statistically different from the others.

The highest mean modulus of elasticity under static bending (Eg) was obtained from wood from stand 12 (9825 MPa), and the lowest was from stand 16 (8433 MPa) (Table 4). For the whole of the studied material, the mean value was $9291 \mathrm{MPa}$, and for individual samples, the values of this parameter ranged from $3259 \mathrm{MPa}$ to $16,490 \mathrm{MPa}$, both extreme values occurring in stand 12 . There were no statistically significant differences in the characteristics of the modulus of elasticity under static bending between stands.

Table 4. Characteristics of modulus of elasticity under static bending $\mathrm{Eg}_{12}(\mathrm{MOE})(\mathrm{MPa})$ of diverse genetic origins ( $\mathrm{N}$-Number of groups; $\mathrm{M}$-Average; Me-Median; Min-Minimum; Max-Maximum; SD-Standard deviation; V-Coefficient of variation).

\begin{tabular}{cccccccc}
\hline Origin & $\mathbf{N}$ & $\mathbf{M}$ & $\mathbf{M e}$ & $\mathbf{M i n}$ & $\mathbf{M a x}$ & $\mathbf{S D}$ & $\mathbf{V}$ \\
\hline 5 & 101 & 9534 & 9829 & 4014 & 16,080 & 3002 & 31.48 \\
7 & 102 & 9227 & 9448 & 3378 & 15,760 & 3108 & 33.68 \\
10 & 92 & 9191 & 9089 & 4349 & 14,830 & 2775 & 30.19 \\
12 & 89 & 9825 & & 3259 & 16,490 & 3269 & 33.27 \\
13 & 118 & 9353 & 9971 & 3815 & 14,660 & 2846 & 30.42 \\
15 & 85 & 9268 & 9343 & 3653 & 15,080 & 2925 & 31.56 \\
16 & 72 & 8433 & 8870 & 3525 & 12,820 & 2430 & 28.82 \\
$\Sigma / M$ & 659 & 9291 & 9451 & 3259 & 16,490 & 2940 & 31.65 \\
\hline
\end{tabular}

The highest mean value of the index of strength quality under compression along the fibres (JRc) was determined from pine wood from stand $15(8.72 \mathrm{~km})$, and the lowest was from stand $16(8.28 \mathrm{~km})$ (Table 5). For the whole of the studied material, the mean value of this index was $8.42 \mathrm{~km}$, and values for individual samples ranged from $3.50 \mathrm{~km}$ (stand 10) to $10.48 \mathrm{~km}$ (stand 15).

Table 5. Characteristics of JRc $(\mathrm{km})$ of diverse genetic origins (N-Number of groups; $\mathrm{M}-$ Average; Me-Median; Min-Minimum; Max-Maximum; SD—Standard deviation; V-Coefficient of variation).

\begin{tabular}{cccccccc}
\hline Origin & $\mathbf{N}$ & $\mathbf{M}$ & $\mathbf{M e}$ & $\mathbf{M i n}$ & $\mathbf{M a x}$ & $\mathbf{S D}$ & $\mathbf{V}$ \\
\hline 5 & 101 & 8.47 & 8.85 & 5.57 & 10.36 & 1.19 & 14.00 \\
7 & 102 & 8.41 & 8.76 & 4.54 & 10.35 & 1.28 & 15.18 \\
10 & 92 & 8.25 & 8.50 & 3.50 & 10.09 & 1.32 & 15.96 \\
12 & 89 & 8.41 & 8.71 & 5.10 & 10.10 & 1.27 & 15.14 \\
13 & 118 & 8.42 & 8.71 & 5.23 & 10.47 & 1.30 & 15.40 \\
15 & 85 & 8.72 & 9.06 & 4.93 & 10.48 & 1.15 & 13.21 \\
16 & 72 & 8.28 & 8.42 & 5.93 & 10.08 & 1.00 & 12.06 \\
$\sum / \mathrm{M}$ & 659 & 8.42 & 8.72 & 3.50 & 10.48 & 1.23 & 14.61 \\
\hline
\end{tabular}


There were no statistically significant differences in the characteristics of JRc between genetic origins.

The highest mean value for the index of strength quality under static bending (JRg) was obtained from wood from stand $12(19.15 \mathrm{~km})$, and the lowest was from stand 16 $(17.20 \mathrm{~km})$ (Table 6). The mean value of this index for the whole of the studied material was $18.23 \mathrm{~km}$, and values for individual samples ranged from a minimum of $3.68 \mathrm{~km}$ (stand 10) to a maximum of $38.35 \mathrm{~km}$ (stand 5).

Table 6. Characteristics of $\mathrm{JRg}(\mathrm{km})$ of diverse genetic origins ( $\mathrm{N}-$ Number of groups; $\mathrm{M}-$ Average; Me-Median; Min-Minimum; Max-Maximum; SD—Standard deviation; V—Coefficient of variation).

\begin{tabular}{cccccccc}
\hline Origin & $\mathbf{N}$ & $\mathbf{M}$ & $\mathbf{M e}$ & $\mathbf{M i n}$ & $\mathbf{M a x}$ & $\mathbf{S D}$ & $\mathbf{V}$ \\
\hline 5 & 101 & 17.89 & 19.11 & 4.65 & 38.35 & 4.85 & 27.13 \\
7 & 102 & 18.37 & 19.23 & 6.79 & 24.29 & 3.80 & 20.69 \\
10 & 92 & 17.73 & 18.49 & 3.68 & 24.31 & 3.97 & 22.39 \\
12 & 89 & 19.15 & 20.15 & 9.86 & 27.49 & 3.90 & 20.36 \\
13 & 118 & 18.69 & 19.65 & 7.74 & 30.59 & 4.24 & 22.71 \\
15 & 85 & 18.29 & 19.01 & 8.39 & 23.21 & 3.63 & 19.82 \\
16 & 72 & 17.20 & 18.26 & 5.74 & 22.44 & 3.48 & 20.24 \\
$\sum / \mathrm{M}$ & 659 & 18.23 & 19.01 & 3.68 & 38.35 & 4.06 & 22.30 \\
\hline
\end{tabular}

It was found that analysed populations differ statistically in mean values of JRg at $p<0.05$. Stand 16 is statistically different from the other stands.

For the index of strength quality related to the modulus of elasticity under static bending (JEg), the highest mean value was obtained for wood from stand $12(1838.12 \mathrm{~km})$ and the lowest was from stand $10(1722.19 \mathrm{~km})$ (Table 7). For the whole of the studied material, the mean value was $1790.40 \mathrm{~km}$. Values of the index for individual samples ranged from $621.63 \mathrm{~km}$ (stand 7) to $3920.08 \mathrm{~km}$ (stand 5).

Table 7. Characteristics of JEg $(\mathrm{km})$ of diverse genetic origins (N-Number of groups; $\mathrm{M}-$ Average; Me-Median; Min-Minimum; Max-Maximum; SD—Standard deviation; V-Coefficient of variation).

\begin{tabular}{cccccccc}
\hline Origin & $\mathbf{N}$ & $\mathbf{M}$ & $\mathbf{M e}$ & $\mathbf{M i n}$ & $\mathbf{M a x}$ & $\mathbf{S D}$ & $\mathbf{V}$ \\
\hline 5 & 101 & 1782.90 & 1875.87 & 666.91 & 3920.08 & 460.19 & 25.81 \\
7 & 102 & 1810.59 & 1908.63 & 621.63 & 2709.76 & 421.72 & 23.29 \\
10 & 92 & 1722.19 & 1841.93 & 883.36 & 2391.65 & 370.51 & 21.51 \\
12 & 89 & 1838.12 & 1949.94 & 819.60 & 2537.04 & 384.70 & 20.93 \\
13 & 118 & 1825.90 & 1952.26 & 648.75 & 2759.73 & 416.17 & 22.79 \\
15 & 85 & 1796.95 & 1884.71 & 966.20 & 2427.12 & 379.78 & 21.13 \\
16 & 72 & 1734.54 & 1808.46 & 931.09 & 2162.96 & 323.37 & 18.64 \\
$\sum / \mathrm{M}$ & 659 & 1790.40 & 1878.97 & 621.63 & 3920.08 & 400.45 & 22.37 \\
\hline
\end{tabular}

There were no statistically significant differences in the characteristics of JEg between genetic origins.

There was significant influence of origin for most analysed properties (Table 8). 
Table 8. Observed significance level of origins for some selected traits.

\begin{tabular}{ccc}
\hline Characteristics & HKW (Kruskal-Wallis Test) & $p$ \\
\hline$\rho$ & 25.94 & 0.000 \\
Rc & 14.44 & 0.025 \\
$\operatorname{Rg}$ & 15.64 & 0.016 \\
Eg & 10.20 & 0.016 \\
$J R c$ & 10.55 & 0.103 \\
$J R g$ & 17.48 & 0.008 \\
JEg & 10.93 & 0.091 \\
\hline
\end{tabular}

\section{Discussion}

Scots pine in Poland plays an important role, both in the formation of forests and in the economy [4]. It is subject to extensive phenotypic variability [30], and multiple varieties, climatypes, and ecotypes have been distinguished as a result. Due to the widespread use of Scots pine timber and the importance of its physical and mechanical properties, it is beneficial to study pines of different origins to identify the most valuable stands.

The present study concerned trees of seven different origins grown on an experimental plot at Rogów Forest Experimental Station. The results made it possible to determine the technical quality of pine wood from different parent stands. The seed material originated from areas with different elevations, natural conditions, and lengths of growing season. The experimental stand was located in the same climate and soil conditions and in the same habitat type (FMBF).

As part of IUFRO in 1938 and 1939, Poland participated in a new series of experiments. The study included pine forest from different parts of the country, located at the eastern border. The results of these studies have shown that local pines have always grown the best. In the next series of IUFRO experiments in 1982, the provenance of pine was tested including 5 from Poland and 15 from the following countries: Hungary, Belgium, France, Germany, Latvia, Slovakia, Bosnia, Herzegovina, and others. The experimental plots were located in Wyszków and Sękocin (central Poland). The trees were researched after 35 years of growth. The trees of Polish origin grew the best, while pine populations from southern Europe grew rather poorly and had low survival rates.

Density is one of the most important physical properties of wood and has an impact on its other technical properties $[8,11,31]$. Statistically significant differences were found in the mean density values between the studied stands. From the geographical variability, it is seen that a stand from southern Poland has a lower wood density than a population from the lowland part of the country. Giertych [32] identified mountain populations of pine that were not suitable for cultivation in lowland Poland. The mean density was calculated to be $490 \mathrm{~kg} / \mathrm{m}^{3}$. The smallest value for an individual sample was $340 \mathrm{~kg} / \mathrm{m}^{3}$ (from stand 16), and the highest was $783 \mathrm{~kg} / \mathrm{m}^{3}$ (from stand 10). This property was found to be highly variable between samples. Wood density exhibits variation both between trees and within individual trees [33,34].

A high variability was found in the mean values of compressive strength among the seven populations. Wood is stronger when cut in a direction parallel to the fibres, rather than across the fibres. This results from the anisotropic structure of wood $[13,35,36]$. The mean compressive strength along the fibres measured for Scots pine wood was $43.5 \mathrm{MPa}$. Reported values for European species range from 30 to $70 \mathrm{MPa}$ [22]. The Nowy Targ population (stand 16) in southern Poland is evaluated as being average [37-39]. In terms of variation in breast height diameter, average height, sum of cross-sectional areas at breast height, and log volume, trees originating from that area achieved the worst results in a study of 23 populations [40].

Significant differences were found between the studied pine populations in the case of static bending strength. This refers to the maximum value of stress attained by a tested wood sample. Typical values of bending strength range from 80 to $100 \mathrm{MPa}[13,31,36]$. The lowest bending strength of a single sample was $23.94 \mathrm{MPa}$ from stand 5 (130 m a.s.l.), and 
the highest was seven times greater, at 169.80 MPa from stand 12. According to Krzysik [13], the average static bending strength of knot-free pine wood is $100 \mathrm{MPa}$. Wagenführ [41] gives a range for Pinus sylvestris L. from 35 to $206 \mathrm{MPa}$.

The modulus of elasticity denotes a type of stiffness of wood under various loads. Values of the modulus of elasticity ranged from 6900 to 20,100 MPa. A high value of MOE indicates good wood resistance [42]. The mean values of this index have been found at $9015 \mathrm{MPa}$ [43] and 10,080 MPa [44]. The highest stand density MOE mean is increasing [45].

The results given above on the variation in the technical quality of Scots pine wood with seven different origins confirm the existence of differences within this species in Poland. Polish tree populations present differences in the quality of wood [46]. Trees originating from a mountain population were not successful in lowland areas.

An analysis of the results obtained in this study shows that the differences between the studied populations are statistically significant. This means that it is possible to select the best areas of origin of Scots pine to achieve optimal technical quality of the wood for specific applications.

\section{Conclusions}

It was shown that the technical quality of the wood of Scots pine (Pinus sylvestris L.) growing in the environmental conditions of central Poland, defined based on the physical and mechanical properties, exhibits significant differences depending on its genetic origin.

The origin of the wood was shown to have a significant influence on wood density, compressive strength, static bending strength, and the modulus of elasticity under static bending.

The highest mean density was found from trees originating from stand 10 and stand 5 . The highest values of compressive strength were obtained from trees originating from stands 5 and 12, and the highest static bending strength and modulus of elasticity under static bending were obtained from trees originating from stand 12. The lowest values of the studied properties were obtained from trees originating from stand 16 (Nowy Targ).

The results indicate that it ought to be possible to select the origin of planting material to obtain the highest quality and productivity of future stands.

Author Contributions: Conceptualization, P.K., W.B. and H.L.; methodology, P.K. and H.L.; software, P.K., H.L., H.S. and E.K.; validation, H.L.; formal analysis, E.K. and H.L.; investigation, E.K.; resources, E.K.; writing-original draft preparation, H.L.; visualization-E.K. and P.K.; writing-review and editing, H.L. and P.K. All authors have read and agreed to the published version of the manuscript.

Funding: This research received no external funding.

Data Availability Statement: Not applicable.

Acknowledgments: The paper presents wood obtained from the Department of Forest Silviculture, Institute of Forest Sciences, Warsaw University of Life Sciences.

Conflicts of Interest: The authors declare no conflict of interest.

\section{References}

1. BDL. Available online: http:/ / www.bdl.lasy.gov.pl/portal/ (accessed on 27 October 2020).

2. Andrzejczyk, T.; Żybura, H. Sosna Zwyczajna. Odnawianie Naturalne i Alternatywne Metody Hodowli; PWRiL: Warszawa, Poland, 2012.

3. Ilmurzyński, E.; Włóczewski, T. Hodowla Lasu; PWRiL: Warszawa, Poland, 2003.

4. Kozakiewicz, P. Sosna zwyczajna (Pinus sylvestris L.) -Polskie drewno. Przemyst Drzewny Res. Dev. 2019, 2, 72-77.

5. Paschalis, P. Zmienność jakości technicznej drewna sosny pospolitej we wschodniej części Polski. Sylwan 1980, $124,29-44$.

6. Kamiński, E.; Głowacki, S.; Paschalis, P. Badania Wpływu Zróżnicowanego Obiegu Żywicowania na Wybrane Właściwości Drewna; Dokumentacja naukowa w Inst. Użyt. Lasu i Inż. Leśn.: Warszawa, Poland, 1976.

7. Jelonek, T.; Pazdrowski, W.; Tomczak, A. Właściwości drewna sosny zwyczajnej (Pinus sylvestris L.) na gruntach porolnych w północnej Polsce (Properties of Scots pine (Pinus sylvestris L.) on former agricultural lands in northern Poland). Leśne Pr. Badaw. (For. Res. Pap.) 2009, 70, 277-286. 
8. Dzbeński, W.; Kozakiewicz, P.; Krutul, D.; Hrol, J.; Belkova, L. Niektóre właściwości fizyko-mechaniczne drewna sosny zwyczajnej (Pinus sylvestris L.) rogowskiej jako materiału porównawczego do badań na sośnie proweniencji łotewskiej. In Proceedings of the Materiały 14 Konferencji WTD SGGW “Drewno materiał wszechczasów”, Rogów, Poland, 13-15 November 2000; pp. 31-36.

9. Witkowska, J.; Lachowicz, H. Zmienność gęstości umownej drewna sosny zwyczajnej (Pinus sylvestris L.) w zależności od wybranych czynników. Sylwan 2013, 157, 336-347. [CrossRef]

10. Witkowska, J.; Lachowicz, H. Analiza zmienności gęstości umownej drewna sosny zwyczajnej (Pinus sylvestris L.) wzdłuż wysokości pnia w zależności od wybranych czynników. Przegląd Pap. 2012, 68, 573-578.

11. Kozakiewicz, P.; Jankowska, A.; Mamiński, M.; Marciszewska, K.; Ciurzycki, W.; Tulik, M. The wood of Scots Pine (Pinus sylvestris L.) from Post-Agricultural Lands has Suitable Properties for the Timber Industry. Forests 2020, 11, 1033. [CrossRef]

12. Józefaciuk, J.; Laurow, Z. Zmienność niektórych cech makroskopowych drewna sosny zwyczajnej (Pinus sylvestris L.) na tle typów pokrojowych. Pr. IBL 1974, 466, 1-26.

13. Krzysik, F. Nauka o Drewnie; PWN: Warszawa, Poland, 1978.

14. Zatoń, P.; Będkowski, M.; Buraczyk, W.; Koczan, G.; Kozakiewicz, P. Comparison of dendrometric features of Scots pine trees and wood density from one of genetic origin obtained from the provenance surface in Forest Research Institute in Rogów. For. Wood Technol. 2019, 105, 4-11. [CrossRef]

15. Wodzicki, T.J. Natural factors affecting wood structure. Wood Sci. Technol. 2001, 35, 5-26. [CrossRef]

16. Danusevičius, J. Use of introductions provenances to increase genetic diversity in local Scots pine populations. Biologija 2001, 1, 59-61.

17. Tomczak, A.; Pazdrowski, W.; Jelonek, T.; Grzywiński, W. Jakość drewna sosny zwyczajnej (Pinus sylvestris L.) Część I. Charakterystyka wybranych cech i właściwości wpływających na jego jakość. Sylwan 2009, 153, 363-372.

18. PN-77/D-04227. Drewno. Ogólne Wytyczne Pobierania i Przygotowania Próbek; Polski Komitet Normalizacyjny: Warszawa, Poland, 1977.

19. ISO 4471. Wood. Sampling Sample Trees and Logs for Determination of Physical and Mechanical Properties of Wood in Homogeneous Stands; ISO: Geneva, Switzerland, 1982.

20. PN-77/D-04100. Drewno. Oznaczanie Wilgotności; Polski Komitet Normalizacyjny: Warszawa, Poland, 1977.

21. ISO 13061-1. Physical and Mechanical Properties of Wood. Test. Methods for Small Clear Wood Specimens. Part. 1: Determination of Moisture Content for Physical and Mechanical Tests; ISO: Geneva, Switzerland, 2014.

22. PN-77/D-04101. Drewno. Oznaczanie Gęstości; Polski Komitet Normalizacyjny: Warszawa, Poland, 1977.

23. ISO 13061-2. Physical and Mechanical Properties of Wood. Test. Methods for Small Clear Wood Specimens. Part. 2: Determination of Density for Physical and Mechanical Tests; ISO: Geneva, Switzerland, 2014.

24. PN-78/D-04102. Drewno. Oznaczanie Wytrzymałości na Ściskanie Wzdłuż Włókien; Polski Komitet Normalizacyjny: Warszawa, Poland, 1978.

25. ISO/DIS 13061-17. Physical and Mechanical Properties of Wood. Test. Methods for Small Clear Wood Specimens. Part. 17: Determination of Ultimate Stress in Compression Parallel to Grain; ISO: Geneva, Switzerland, 2014.

26. PN-77/D-04103. Drewno. Oznaczanie Wytrzymałości na Zginanie Statyczne; Polski Komitet Normalizacyjny: Warszawa, Poland, 1977.

27. ISO 13061-3. Physical and Mechanical Properties of Wood. Test. Methods for Small Clear Wood Specimens. Part. 3: Determination of Ultimate Strength in Static Bending; ISO: Geneva, Switzerland, 2014.

28. PN-63/D-04117. Fizyczne i Mechaniczne Własności Drewna. Oznaczanie Wspótczynnika Sprężystości Przy Zginaniu Statycznym; Polski Komitet Normalizacyjny: Warszawa, Poland, 1963.

29. ISO 13061-4. Physical and Mechanical Properties of Wood. Test. Methods for Small Clear Wood Specimens. Part. 4: Determination of Modulus of Elasticity in Static Bending; ISO: Geneva, Switzerland, 2014.

30. Hebda, A.; Wójkiewicz, B.; Wachowiak, W. Genetic characteristics of Scots pine in Poland and reference populations based on nuclear and chloroplast microsatellite markers. Silva Fenn. 2017, 51, 1-17. [CrossRef]

31. Tomczak, A.; Jelonek, T.; Zoń, L. Porównanie wybranych właściwości fizycznych drewna młodocianego i dojrzałego sosny zwyczajnej (Pinus sylvestris L.) z drzewostanów rębnych. Sylwan 2010, 154, 809-817.

32. Giertych, M. Zmienność proweniencyjna sosny zwyczajnej (Pinus sylvestris L.) w Polsce. Sylwan 1997, 8, 5-20.

33. Tomczak, A.; Jelonek, T. Gęstość drewna z bielastej części przekroju poprzecznego sosny zwyczajnej (Pinus sylvestris L.) pochodzacej z wybranych drzewostanów północno-zachodniej Polski. For. Lett. 2014, 107, 5-9.

34. Chmielowski, J.; Kozakiewicz, P.; Buraczyk, W. Variability of annual rings and density of Scots pine (Pinus sylvestris L.) wood of Bolewice origin from the provenance surface in Rogów. Ann. Wars. Univ. Life Sci. SGGW For. Wood Technol. 2018, 102, 11-15.

35. Kozakiewicz, P. Fizyka Drewna w Teorii i Zadaniach; Wydawnictwo SGGW: Warszawa, Poland, 2012.

36. Kokociński, W. Drewno_Pomiary Właściwości Fizycznych i Mechanicznych; Wydawnictwo AR: Poznań, Poland, 2004.

37. Kowaczyk, J.; Matras, J.; Żybura, H.; Sabor, J.; Barzdajn, W. Zmienność sosny pospolitej i hodowlana wartość jej proweniencji. Pr. IBL 2000, 7, 164.

38. Kowalczyk, J.; Matras, J. Badania porównawcze populacyjnej i rodowej zmienności cech hodowlanych wybranych pochodzeń sosny zwyczajnej (Pinus sylvestris L.). Pr. IBL 2006, 1, 1-245. 
39. Gawron, L. Zmienność Cech Wzrostowych i Jakościowych Krajowych Pochodzeń Sosny Zwyczajnej (Pinus sylvestris L.) Rozprawa Doktorska; SGGW: Warszawa, Poland, 2014.

40. Barzdajn, W. Zmienność cech taksacyjnych sosny zwyczajnej (Pinus sylvestris L.) polskich pochodzeń w doświadczeniu proweniencyjnym z 1985 roku w Nadleśnictwie Zielonka. Sylwan 2006, 150, 8-19.

41. Wagenführ, R. Holzatlas; VEB Fachbuchverlag: Leipzig, Niemcy, 2007.

42. Liang, S.; Fu, F. Comparative study on three dynamic modulus of elasticity and static modulus of elasticity for Lodgepole pine lumber. J. For. Res. 2007, 18, 309-312. [CrossRef]

43. Hassan, K.T.S.; Horáček, P.; Tippner, J. Evaluation of Stiffness and Strength of Scots Pine Wood Using Resonance Frequency and Ultrasonic Techniques. BioResources 2013, 8, 1634-1645. [CrossRef]

44. Wood-Database. Available online: https://www.wood-database.com (accessed on 27 October 2020).

45. Šilinskas, B.; Varnagirytė-Kabašinskienè, I.; Aleinikovas, M.; Beniušienė, L.; Aleinikovienè, J.; Škèma, M. Scots Pine and Norway Spruce Wood Properties at Sites with Different Stand Densities. Forests 2020, 11, 587. [CrossRef]

46. Jakubowski, M.; Jelonek, T.; Tomczak, A. Compressive strength parallel to grain of Scots pine wood of wind-Damaged and undamaged trees. Sylwan 2014, 158, 787-794. 